\title{
NEW GENERA AND SPECIES OF STERRHINAE (FAM. GEOMETRIDAE).
}

\section{By LOUIS B. PROUT.}

\begin{abstract}
A S my catalogue of this subfamily in the Lepidopterorum Catalogus is to appear this year, and it is desirable that it should place the species as nearly as possible in the genera to which they are assigned in the long-delayed Genera Insectorum revision, it has become urgent to publish a few genera which have hitherto stood in manuscript only. At the same time, there is some danger of a collision with the Sterrhinae in Seitz, at least as regards Vol. XVI, for which the manuscript is completed, but not likely to be published for several months. I have therefore added diagnoses of several species which otherwise would have awaited publication in that work.
\end{abstract}

\section{Metallaxis gen. n.}

๙. Palpus short, terminal joint small. Antenna fasciculate. Hindtibia with a pair of spurs (type) or spurless ; (semipurpurascens Hmpsn.) with four spurs. - Forewing with cell rather short, $\mathrm{DC}^{1}$ usually short, areole double, $\mathrm{SC}^{2}$ from cell, $\mathrm{R}^{2}$ normal._Hindwing with termen weakly bent at $\mathrm{R}^{3}$, cell rather short, C normal, $\mathrm{SC}^{2}-\mathrm{R}^{1}$ shortly stalked, $\mathrm{R}^{2}$ central, $\mathrm{M}^{1}$ separate. Genitalia show in the aborted mappa, etc., a near relationship to Rhodostrophia, whereas Somatina approaches Scopula.

Type of the genus : Metallaxis semiustus (Swinh.) ${ }^{\circ}=$ Erythrolophus semiustus Swinh. (1894).

To the two hitherto known species (the type and "Rhodostrophia" semipurpurascens Hmpsn., 1896) I add provisionally :

\section{Metallaxis teledapa sp. n.}

of, 18-21 mm. Smaller than the two Indian species, cell of forewing a little less short, hindwing with abdominal margin relatively longer. Hindtibia with strong pencils, without spurs, tarsus nearly $\frac{3}{5}$. Whitish buff, the forewing irregularly (chiefly in posterior part and median area) irrorated with vinaceous cinnamon, the irroration largely confluent.—Forewing with dark admixture at base and (more leaden) along a large part of costal margin ; an ill-defined longitudinal line along $\mathrm{M}$ and proximal part of $\mathrm{M}^{2}$; antemedian line fine, curving outward to near cell-mark, sometimes obsolescent anteriorly; postmedian fine, excurved; a rather oblique mark in distal area between the radials and a tornal patch as far as $\mathbf{M}^{2}$. ——Both wings with a dark terminal line.- Underside paler, weakly marked.

Madagascar: Diego Suarez, 12 హิ ô (G. Melou), type in Mus. Tring.

\section{Pseuderythrolophus gen. n.}

Palpus with 3rd joint short, especially in the $\hat{\delta}$. Antenna of $\hat{o}$ bipectinate to beyond middle, with very strong branches. Hindtibia of $\hat{\delta}$ strongly thickened and tufted, without spurs, of $q$ with 3 spurs. Abdomen rather robust, in $\hat{\sigma}$ 
with lateral tufts on last two segments._-Forewing with areole double, $\mathrm{SC}^{2}$ from cell, $\mathrm{R}^{2}$ central.—Hindwing with $\mathrm{SC}^{2}$ just separate, $\mathrm{R}^{2}$ central, $\mathrm{M}^{1}$ arising near $\mathrm{R}^{3}$.

Type of the genus: Pseuderythrolophus bipunctatus (Warr.) = Erythrolophus bipunctatus Warr. (1899).

A comparison of the structure with that of Erythrolophus was given in Ann. Mag. Nat. Hist. (10) vi. 690.

\section{Apostegania gen. $\mathrm{n}$.}

Palpus rather short. Antenna of $\hat{\sigma}$ with fascicles of cilia, of $q$ also well ciliated. Midtibia of $\hat{\sigma}$ with the spurs very unequal; hindtibia of $\hat{\sigma}$ with a single (strong) spur, of $q$ with a pair of spurs._- Forewing with cell short $\left(\frac{2}{5}\right.$ or barely), areole double, $\mathrm{SC}^{2}$ from cell, $\mathrm{R}^{2}$ normal._Hindwing with cell short ( $\frac{2}{5}$ or less), C normal, $\mathrm{SC}^{2}$ about connate or very shortly stalked, $\mathrm{R}^{2}$ normal, $\mathrm{M}^{1}$ separate. Genitalia $(\hat{o})$ of the Rhodostrophia type but with gnathos undeveloped.

Type of the genus: Apostegania crina (Swinh.) = Stegania crina Swinh. (1892).

It is strange that Hampson, who worked largely by venation, did not discover Swinhoe's incorrect subfamily reference; see Faun. Ind., Moths, iii. 166. To the present genus, which is unique in the one-spurred $\hat{o}$ hindtibia, must be added "Ptochophyle" rectilineata Swinh. (1906), which, however, is irregular in that the $\hat{o}$ hindleg has a femorotibial hair-pencil and a dense tuft on lst tarsal joint.

\section{Tricentra benevisio sp. n.}

ธิ, $15 \mathrm{~mm}$. Face rosy. Palpus rosy above, pale yellow beneath. Vertex yellow, with slight rosy suffusion. Antennal shaft rosy. Body yellow, irrorated and spotted with rose-colour. Foreleg largely rosy. Hindtibia with both proximal spurs present, but short, one sometimes vestigial. Wings shaped as in gavisata (Walk., 1862). Yellow with rosy irroration and suffused (except extreme termen and fringes and on forewing a restricted area about the medians) with vinaceous ; markings much as in gavisata, but with cell-spots of forewing yellow, confluent, subterminal shade weaker, more diffuse, on forewing less bent.

E. Bolivia: Buenavista, 750 m., January-April 1907 (J. Steinbach), type in coll. Joicey.

\section{Semaeopus maleformata sp. n.}

ô, $33 \mathrm{~mm}$. Antennal ciliation not long. Midleg simple. Hindtibia and tarsus strongly dilated and tufted.

Forewing with termen faintly subconcave anteriorly, rather strongly bent at $\mathrm{M}^{1}$, thence strongly oblique; $\mathrm{SC}^{2}$ stalked, distal areole very small; colour and markings closely as in scripturata (Warr., 1906), antemedian rather thicker, less incurved, posteriorly less oblique.-Hindwing rather narrow, termen straightish from apex to $\mathrm{M}^{1}$, here strongly toothed, weakly subconcave between tooth and tornus; SC and M converging distally ; tufts of long, backwarddirected hair from cell beneath, abdominal region beneath also somewhat hairy ; like scripturata, but with marginal cloudings more reddish than smoky; hairs of underside ochreous.

Uruguay: Santa Cruz (Spencer Moore, collected during the Matto Grosso Expedition, 1891-92), 1 ơ in Mus. Brit. 


\section{Neothysanis aloxogramma sp. n.}

ô, $20 \mathrm{~mm}$. Near imella (Druce, 1899), of which bicolor Dogn. (1900, genotype) is perhaps an aberration. (Hindlegs lost.)

Forewing perhaps variable in ground-colour; proximal area and apical part of distal in the type paler and more mixed with yellowish, the rest more purple-brown; distinguishable at a glance from the other Neothysanis by the very different form of the lines, the antemedian being excurved or outbent in the cell and somewhat waved throughout, the postmedian from costa at $\frac{2}{3}$ to hindmargin at $\frac{2}{3}$, gently sinuate; cell-spot moderate, slightly elongate; illdefined anterior dots and posterior cloud close to termen.-Hindwing more unicolorous than forewing; central line slightly excurved.

Forewing beneath with distal area and hindmargin pale grey, the rest purple-brown ; cell-dot black; postmedian line somewhat sinuous, excurved at hindmargin, more distal than above, beginning in a slightly thickened spot at fully $\frac{4}{5}$ costa. Hindwing with costal region tinged with reddish, the rest grey; a black cell-dot; a fine, rather irregular postmedian line, with a rather strong sinus inward between the radials.

Bolivia: Rio Suruta, Dep. Santa Cruz, 400 m. (J. Steinbach), type in coll. Joicey.

The lines are too differently formed to allow of our regarding this as a possible aberration of imella, which also occurs in the same locality. Both species have the areole double, the dividing wall from about end of cell, similar antennal structure, etc., but the angles at $\mathrm{R}^{3}$ are perhaps slightly the less strong in aloxogramma.

\section{Asellodes platygymna sp. n.}

ô, 28-29 mm. Head white, with a greenish-yellow tinge ; occiput fleshcoloured ; palpus with 2nd joint upcurved, a fleshy streak on outerside. Hindtibia and tarsus extremely short and aborted, a longish light-brown pencil on innerside.

Forewing similar in shape and coloration to that of laternaria Guen., slightly narrower, the elbow or tooth at $\mathrm{M}^{1}$ less appreciable, the coloration slightly paler ; subhyaline area still more extended, basal patch with boundary straighter and less oblique, hind border limited for a much longer distance by $\mathrm{SC}^{2}$, terminal border somewhat reduced; instead of the single triangular subcostal projection at end of cell which characterizes laternaria, two such projections, the smaller crossing the proximal areole and just entering the cell, the larger at and beyond the end of distal areole and crossing $\mathrm{R}^{1}$. Hindwing shaped more as in constellata (Warr., 1904) than in laternaria, but with the teeth even weaker; the floccous patch which in laternaria runs along the underside from tornus to the hook at $\mathrm{R}^{1}$ almost wanting, merely indicated at tornus ; subhyaline area much ampler than in laternaria, absorbing and over-reaching the spot in the angle of $\mathrm{SC}^{2}$ and $\mathrm{R}^{1}$; costal spot reduced, separated from basal patch.

Underside mostly pale ; forewing with the proximal part of costa, the costal spots and proximal part of distal border, at least anteriorly, more or less strongly pink; the rest of the markings indicated by an increased opaqueness.

Bolivia: Prov. del Sara, Dep. Santa Cruz, 450 m., January (J. Steinbach), 2 ơ ở in coll. Joicey. 


\section{Ptochophyle dollmani sp. n.}

Of about the shape of hilaris Warr. (1898), but considerably larger (27 mm.), the postmedian line much more distally placed, not widened into a band, on the forewing more sinuous ; central area of forewing variegated with bright red and black-grey. Underside similarly marked, the hindwing a little paler, the red of the forewing less bright, but suffusing also a part of the proximal area.

N.W. Rhodesia: Solwezi, April 1918 (H. C. Dollman), type ô in Mus. Brit.

\section{Ptochophyle apseogramma sp. n.}

Near rubripennis (Warr., 1898, Chrysolene) = sanguinolenta (Warr., 1898), perhaps a form. Not quite so broad-winged; forewing with the lines somewhat more approximated, the antemedian less bent at its ends; hindwing with the 2nd line more sharply angled, cut at its angle by a broad longitudinal creamyellow line which runs in front of $\mathrm{M}$ and $\mathrm{R}^{3}$, starting proximally of the 1st line and continuing, though slender, as far as the macular subterminal.

N.W. Rhodesia : Solwezi, 6 December 1917 (H. C. Dollman), type ô in Mus. Brit.

\section{Ptochophyle subminiosa sp. n.}

+, $27 \mathrm{~mm}$. Hindwing more angled than in rubripennis and apseogramma. Colour less bright (yellow, mixed with pink). Forewing with an elongate dark cell-mark (as in miniosa Warr., 1899), lines fine and weak, faintly dark-edged in median area, the antemedian acutely angled in cell, the postmedian as sinuous as in miniosa, but nearer to the cell-spot. Hindwing still more weakly marked, the cell-spot white, very small.

N.W. Rhodesia: Mwengwa, 30 December 1913 (H. C. Dollman), type in Mus. Brit.

\section{Ptochophyle hyalotypa sp. n.}

27-28 $\mathrm{mm}$. Head between the antennae whiter than in rubripennis (Warr.) ; forewing slightly narrower, duller, more vinaceous-brown, lines less oblique, less uniformly developed throughout; hindwing quite distinct in shape, forming a blunt tail at $\mathrm{R}^{3}-\mathrm{M}^{1}$. Coloured as forewing, but with a somewhat hyaline white spot, which interrupts the 2nd yellow line.

Lake Kivu: Rugege Forest, Ruanda district, 7,000 feet, December 1921 (T. A. Barns), 2 ơ ổ in coll. Joicey.

\section{Ptochophyle zombensis sp. n.}

$29 \mathrm{~mm}$. Rosy, almost entirely washed over with pale purple-drab and with bright gold-yellow borders and fringes; in shape and coloration extremely like a $q$ of togata (Fb., 1798) ; cell-spot of hindwing pale primrose-yellow, not white ; forewing above with a small red cell-dot ; faint red ante- and postmedian lines, the latter more strongly outbent in the middle than on the forewing of hyalotypa.

Nyasaland : Zomba, April-May 1925 (H. Barlow), type $q$ in coll. Joicey.

\section{Ptochophyle eclipsis sp. n.}

+ , $29 \mathrm{~mm}$. Head and body concolorous with wings.

Forewing with costa very slightly arched at base and near apex, termen markedly oblique, sinuous, between $\mathrm{SC}^{5}$ and $\mathrm{R}^{3}$ and between $\mathrm{M}^{1}$ and $\mathrm{SM}^{2}$ slightly 
concave ; dark grey, tinged with vinaceous ; a more blackish cell-spot suggested ; markings mostly buff-yellow ; six irregular costal spots, appearing slightly more orange-buff on account of some red irroration, the three proximal small, the three distal larger; faint suggestions of a curved, macular antemedian from spot 2 ; some red irroration between spots 3 and 5 , connected with a highly irregular and incomplete postmedian of a deep hellebore-red colour (or a little redder), which forms a longitudinal streak in front of $\mathrm{R}^{1}$, is distinctly double and dentate from $\mathrm{R}^{1}$ to $\mathrm{M}^{1}$, then very weak, hardly more than red irroration ; subterminal buff-yellow, from spot 6 , macular, interrupted between $\mathrm{R}^{3}$ and $\mathrm{M}^{1}$; a similar, but slightly narrower and (except between $\mathrm{R}^{3}$ and $\mathrm{M}^{1}$ ) more continuous line close to termen, arising from a costal dot or dash.-Hindwing termen with the first concavity $\left(\mathrm{R}^{1}\right.$ to $\left.\mathrm{R}^{3}\right)$ more pronounced, the second short and weak; $\mathrm{SC}^{2}$ connate ; concolorous with forewing, the only distinct marking an irregular buff-yellow antemedian between cell-fold and hindmargin.

Underside mostly less dark; the outer two lines much paler yellow, fused into a band which is interrupted between $\mathrm{R}^{3}$ and $\mathrm{M}^{1}$, bears some vinaceous vein-dots and is continued on hindwing; base of wings also with some pale yellow, the rest largely suffused with vinaceous, the forewing, however, retaining an ample but ill-defined dark-grey area in and around cell.

Madagascar: Station Perinet, $149 \mathrm{~km}$. E. of Tananarivo, 20 October-10 November 1930 (Mme. N. Olsoufieff), 1 $\%$ in coll. Tring. Mus.

The peculiar coloration of the upperside suggests that this may be an aberration, but the shape distinguishes it from all the known Ptochophyle of the African Region. The subterminal maculation has something in common with that of rubripennis (Warr., 1898).

\section{Chrysocraspeda rosina heterora subsp. n.}

Differs from $r$. rosina Warr. (1898) in having yellow subterminal spots, especially between $\mathrm{R}^{3}$ and $\mathrm{M}^{1}$, the yellow border of the forewing widening more triangularly in its posterior part, the hindwing perhaps more acutely angled at $\mathrm{R}^{3}$.

French Guinea: Soundedou, near Macenta, 1,600 feet, 13 May 1926 (C. L. Collenette). Type ô in coll. Joicey.

Possibly a distinet species.

\section{Chrysocraspeda heringi sp. n.}

ㅇ, $20 \mathrm{~mm}$. Forewing rather narrower than in rosina Warr., termen more regularly curved. More mixed with yellow (especially in proximal area of forewing) and with dark irroration; cell-spots black, that of hindwing elongate ; a yellow postmedian narrow band or thick line, on the forewing sinuous, on the hindwing bent parallel with termen ; forewing also with interrupted yellow subterminal and indication of curved dark antemedian. Hindwing beneath much paler. S. Cameroons : Lolodorf, type $q$ in Zool. Mus. Berlin.

\section{Ptomophyle gen. n.}

Palpus rather short; 3rd joint rather small, especially in the $\hat{\sigma}$. Antenna in the $\delta$ with long pectinations, apical $\frac{1}{6}$ merely ciliated; in the $q$ with very short ciliation. Hindtibia in both sexes with all spurs. Forewing with apex acute, termen bent in middle, areole single, $\mathrm{SC}^{1}$ from its apex or oftener stalked beyond, 
cell somewhat shortened, with $\mathrm{M}^{1}$ connate or stalked. Hindwing with apex pronounced, a blunt angle at $\mathrm{R}^{3} ; \mathrm{R}^{1}$ connate or stalked, $\mathrm{M}^{1}$ stalked.

Type of the genus; Ptomophyle subcarnea (Warr.) = Traminda subcarnea Warr. (1902).

Differs from Ptochophyle Warr. (=Chrysolene Warr.) in the point of origin of $\mathrm{M}^{1}$ of the forewing. The $\sigma^{1}$ genitalia, moreover, which in Ptochophyle agree pretty closely with those of Calothysanis (= Timandra) have more in common with Traminda, but show no signs of the complicated uncus.

\section{Traminda vividaria (Walk.).}

Timandra vividaria Walk., List Lep. Ins. xxiii. 800 (1861) (Caffraria).

The pink forms of this variable and very widely distributed species should be called, by analogy with those of $T$. ocellata Warr. (1895), ab. rufa ab. n.

\section{Traminda obversata atroviridata (Saalm., 1880).}

This race, which differs from the continental o. obversata (Walk., 1861) in having the line firm, not punctiform, also produces a pinkish aberration (rufa ab. n.). I have not yet seen such in the very common and generally distributed name-type.

\section{Anisodes connexa (Warr.) Prout.}

Anisodes radiata and ab. connexa Warr., Nov. Zool. xiv. 214 (1907) (Cushi, Huánuco).

As the species earlier described as Perixera (?) radiata Warr. (Nov. Zool. iv. 221, 1897, Bonthain, Celebes) is also an Anisodes, I propose to call the dimorphic Peruvian species by the second of the two names which were contemporaneously erected by Warren. Those who so desire are still at liberty to call the form in which the longitudinal streak is subobsolete "ab. radiata," or to give it a new name.

It should be added that logically, according to the spirit of the requirements of binary nomenclature for the species, the name which ought to be altered in such cases of collision as the present is the one which obtains later admission into the genus wherein a species bearing the same name was primarily erected. But as the apparently universal custom has been to regard the chronology of the species-name as the sole criterion, I am willing to sacrifice logic to uniformity.

\section{Anisodes polysticta nom. n.}

Anisodes multipunctata Warr., Nov. Zool. xi. 509 (1904) (nom. praeoce.) (Carabaya, S.E. Peru).

"Perixera" multipunctata Warr., Nov. Zool. vi. 336 (1899), from Milne Bay, is also an Anisodes; if, however (or so long as), this latter can be regarded as an absolute synonym of thermosaria (Walk., 1862, Sarawak), the new name may be considered as superfluous - another illustration of the complications that are involved in " secondary homonymy."

\section{Anisodes irregularis rothschildi nom. n.}

Anisodes warreni Rothsch., Lep. Br. Orn. Un. Exp. 96 (1915) (nom. praeoce.) (Snow Mountains).

Lord Rothschild overlooked that M. Dognin had already (Mém. Soc. Ent. Belg. xxii. 9, 1913) dedicated an Anisodes from Colombia to Mr. Warren. The Snow Mountains insect is at most a race of Anisodes (Plocucha) irregularis Warr. 
(1896) from Humboldt Bay, of which only the two originals - less sharply marked, at least as regards the ocellus of the hindwing - are yet known to me ; further material may perhaps necessitate the merging of the two.

\section{Anisodes misella nom. n.}

Pisoraca (?) inornata Warr., Nov. Zool. v. 241 (1898) (nom. praeoce.) (Nigeria).

Both this and "Brachycola (?)" inornata Warr., Nov. Zool. iv. 216 (1897) are now referred to Anisodes.

\section{Anisodes obviata nom. n.}

Eremocentra stramineata Warr., Nov. Zool. xiv. 141 (1907) (nom. praeocc.) (Biagi, British New Guinea).

Warren in 1900 (Nov. ZooL. vii. 145) described an Anisodes stramineata from Ecuador.

\section{Anisodes pantophyrta sp. n.}

of, $34 \mathrm{~mm}$. Face impure white, mixed with red above. Palpus long, 3rd joint not much shorter than 2nd ; red above, whitish beneath. Head, antennal shaft, thorax and anterior part of abdomen rood's brown above; abdomen anteriorly with some red on side ; last few segments of abdomen and underside whitish. Hindfemur and tibia glabrous, the tibia well over $\frac{1}{2}$ femur, a single long spur as in denticulata Hmpsn. (1895) - section Eremocentra Warr.

Forewing with areole ample, $\mathrm{SC}^{5}$ just before its end ; slightly greyer than rood's brown, irregularly marked with antimony yellow ; some mottling proximally; an antemedian band between $\mathrm{SC}$ and hindmargin in and behind end of cell, interrupted at $\mathrm{M}$, widening a little behind ; postmedian spots between $\mathrm{SC}^{5}$ and $\mathrm{R}^{3}$ and between fold and $\mathrm{SM}^{2}$, the anterior one quite near two subterminals, which are central and subapical ; a row of black vein-dots just proximal to subterminal spots, inbent at $\mathrm{R}^{2}$ so as to approach postmedian spot.-Hindwing with a similar but somewhat reduced pattern in outer half.

Underside very much paler, with shadowy cloudings and on forewing weak outer vein-dots.

British New Guinea: Upper Aroa River, March 1903 (A. S. Meek), 1 ơ in coll. Tring Mus.

\section{Anisodes hirtifemur sp. n.}

Like lyciscaria Guen. (= bitactata Walk.), which it evidently represents in Southern Nigeria. Distinguishable by the of hindleg, which has the femur fringed with coarse hair and the proximal spur of the tibia shortened. Face with the red (upper) part restricted-less than $\frac{1}{2}$ (in lyciscaria about $\frac{2}{3}$ ). Cell-dot of hindwing sometimes sharply outlined with black.

Warri (including the type) and Degama, a short series in Mus. Tring.

Ab. bitactata ab. n., has dark distal cloudings as in name-typical lyciscaria, the simpler type-form corresponding to lyciscaria ab. caecaria Guen.

\section{Anisodes proconcava sp. n.}

ơ, $20-22 \mathrm{~mm}$. Group of megista Druce (1892). Palpus in both sexes similarly elongate. Hindtibia in ô densely clothed with long coarse hair, proximal spur (as in the whole group) wanting. Head and body concolorous with 
wings, the face and upperside of palpus a little more reddened ; the slight crests of abdomen whitish.

Forewing in of with costal margin sinuous, between the small basal and the longer distal convexity faintly but quite appreciably concave, apex not produced, termen in anterior part curved and faintly waved, posteriorly straighter and fairly strongly oblique ; areole well developed (in 오 sometimes small) ; groundcolour pale, suffused almost throughout with avellaneous, much as in argenticristata Warr. (1901), thus decidedly less warm than in most of the group ; anteand postmedian series of vein-dots distinct, much as in the last-named, the white cell-dot rather strongly outlined in blackish, the median shade almost or quite touching it on distal side.—Hindwing with abdominal margin relatively rather long, at least in the $\hat{\jmath}$, termen subcrenulate; markings corresponding to those of forewing.

Underside anteriorly suffused with pinkish, the hindmargin of forewing and almost the whole of hindwing pale ; markings - except on pale part of forewing much as above, the antemedian slight.

Mexico, Costa Rica, N. Venezuela and Fonte Boa, the typical series from San Esteban, Venezuela (S. M. Klages), in Mus. Tring.

Differs from argenticristata in coarsely clothed hindtibia, in shape, and in presence of the areole.

\section{Pleuroprucha archigetes sp. n.}

§ิำ, 19-23 mm. Extremely like rudimentaria (Guen., 1858). Palpus with 3rd joint longer. Hindtibia of 0 with 4 spurs. Average size larger ; tone, as compared with the pinkish-red shade of rudimentaria, rather more orange-red or brown-red ; markings rather stronger ; median shade of forewing rather broad. Hindwing with $\mathrm{M}^{1}$ connate to stalked.

Venezuela to French Guiana, the type of from Potaro River, British Guiana, April 1908 (S. M. Klages), in coll. Tring Mus. Perhaps also in Central America.

The obviously very close relationship of this species and the following to the typical Pleuroprucha precludes the possibility of our considering the irregularities in their $\hat{o}$ hindtibial armature as generic. Similar irregularities are already admitted in the closely allied genus Anisodes.

\section{Pleuroprucha protopages sp. n.}

ऽำ, 17-19 mm. Also extremely like rudimentaria Guen., but with the 3rd joint of the palpus longer. Hindtibia of of with 3 spurs. Average size small ; tone, as compared with rudimentaria, redder ; markings moderate in expression (in rudimentaria generally weak). Hindwing with $\mathbf{M}^{1}$ stalked.

French Guiana, the type (in coll. Tring Mus.) and a number of others from the Maroni River. Also from Parà.

\section{Myrice steinbachi sp. n.}

ô, $23 \mathrm{~mm}$. Head orange. Palpus dark grey, beneath orange. Antenna with the fascicles of cilia on the first six joints virtually sessile, the succeeding joints progressively dentate-fasciculate, but with the teeth continuing shorter than in inaequalis (Walk., 1854, as Asiona). Body grey, the thorax largely 
(especially above) overlaid with orange. Hindfemur, as in inaequalis, broadened, somewhat hollowed on outerside, the tibia somewhat shorter than in that species (little longer than femur), somewhat dilated, one of the spurs reduced to a knob, the other moderate, rather blunt.

Forewing relatively slightly shorter than in inaequalis; uniform grey, the veins little or scarcely darkened.—Hindwing uniform grey.

Underside the same, the costal margin of the forewing a little darker or more densely scaled.

Bolivia: Prov. del Sara, Dep. Santa Cruz, 450 m. (J. Steinbach), 2 ơ ô in coll. Joicey.

Shape more as in transiens Walk. (1854), but with no trace of the white innermarginal spot, etc.

\section{Isoplenodia gen. $\mathrm{n}$.}

Palpus very short and slender. Antenna of $\hat{\jmath}$ bipectinate with long branches, as in Epicosymbia, in $q$ also pectinate, but more shortly than that of Isoplenia. Hindtibia of $o$ shortened and broadened, spurless, fringed above and with a hairpencil ; of $q$ with 2 spurs._Forewing shaped much as in Epicosymbia; areole double, $\mathrm{SC}^{2}$ from cell.—Hindwing with $\mathrm{SC}^{2}$ shortly stalked.

Type of the genus: Isoplenia arrogans sp. n.

Differs from Epicosymbia in the very short palpus, the + antenna and the hindtibia.

\section{Isoplenodia arrogans sp. $\mathrm{n}$.}

ô, 18-19 mm. ; ᄋ, $23 \mathrm{~mm}$. In ground-colour like the much larger Epicosymbia dentisignata (Walk., 1862) and Isoplenia trisinuata Warr. (1897), but with more purplish irroration. Vertex and antennal shaft pure white.

Forewing with cell-dot small, but sharply black, median shade much more proximally placed than in the species named; terminal line interrupted.Hindwing with similar distinctions.

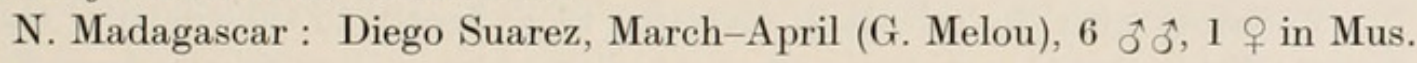
Tring.

Ab. degener ab. n. (? sp. div.) is less reddish, without purple suffusions, the markings weaker, terminal line obsolete, $\mathrm{SC}^{2}$ of hindwing scarcely stalked. $1 \hat{o}$, 23 August 1917.

\section{Somatina rhodochila sp. n.}

ô, $32 \mathrm{~mm}$. Head and antenna dull red; antennal ciliation 1.

Forewing rather elongate ; venation normal ; distinct in its olive-buff and rosy suffusions and coarse black irroration ; costal and distal borders pink ; cellmark crescentic ; very vague sinuous postmedian and subterminal lines indicated, formed somewhat as in purpurascens Moore (1867) or still more oblique costally. -Hindwing with termen roundly bent, weaker-marked, an ill-defined vinaceous-cinnamon apical cloud.

Underside dirty whitish, unmarked; costal margin of forewing buff, at extreme edge redder ; fringes dull purplish.

W. Kivu ; south side of middle Lowa Valley, 3,500 feet, forest, March 1924, wet season (T. A. Barns), 2 ô ồ in coll. Joicey. 


\section{Somatina ioscia sp. n.}

Rather larger and broader-winged than sedata Prout (1922), the head and costal edge without any ochreous colour.

Wings pale grey with rather strong lilac-grey reflections and with some fine olive-grey irroration ; the indistinct olive-grey lines are sinuous, in part dentate, and commence from characteristically darkened and oblique costal streaks on the forewing; distal areole extremely small.

Matoppas, Bulawayo, 14 March 1923 (R. Stevenson), type $q$ in coll. Transvaal Mus.

\section{Somatina figurata candida subsp. n.}

Differs from $f$. figurata Warr. (1897) in having the ground-colour white, almost as pure as in vestalis (Butl., 1875).

Uganda, the type a of from Wakibara, Unyoro (Dr. Ansorge), in Mus. Tring.

\section{Problepsis rorida sp. n.}

ô, $39 \mathrm{~mm}$. ; $+50 \mathrm{~mm}$. ô pectinations fairly long, gradually diminishing, to become mere teeth at about the 38 th-40th joints; hindtarsus scarcely over $\frac{1}{3}$ tibia.

Forewing with markings weak, the silvery cell-mark without any dark element, median line just distal thereto, postmedian complete, dentate.Hindwing similarly marked, the cell-mark expanded posteriorly by means of a proximal projection, median just proximal to it.

Nyasaland: Mt. Mlanje, 10 May 1913, type ơ in Mus. Tring; the larger, robust and broad-winged $q$ in Mus. Brit., collected at 6,000-7,000 feet, 2 May 1910 (S. A. Neave). Formerly misidentified as latonaria Guen.

\section{Problepsis neumanni sp. n.}

ô, $36 \mathrm{~mm}$. Structure and shape nearly as in similinotata Prout (1917), the pectinations scarcely so short.

Forewing with the cell-mark reverting more nearly to the shape of that of aegretta Feld. (1875), without anterior prolongation; lines fine and weak, the postmedian almost obsolete anteriorly.

S.W. Abyssinia: Djiren, Djimma, 20 May 1925 (O. Neumann), type in Mus. Tring.

\section{Ignobilia gen. n.}

Palpus moderate, 2nd joint straight, appressed-scaled, reaching well beyond face, 3rd joint shortish-moderate. Antenna in of with moderate, well-ciliated pectinations, ending in short, slight fascicles; in $q$ minutely ciliated. Pectus slightly hairy. Hindtibia in ô spurless, with dense pencils, tarsus short, partly concealed; in $q$ with 4 spurs.—Forewing rather broad, costa arched, apex acute, termen faintly sinuous, little oblique, tornus well expressed ; cell short, $\mathrm{DC}^{1}$ rather long; areole double, the distal usually very small, the dividing wall from stalk of $\mathrm{SC}^{3-5} ; \mathrm{SC}^{1}$ and $\mathrm{SC}^{5}$ from distal areole, $\mathrm{SC}^{2.3 .4}$ very long-stalked from its apex ; $\mathrm{R}^{2}$ from somewhat before middle of DC (considerably less extreme than in Nobilia), $\mathrm{M}^{1}$ separate._Hindwing with costa rather long, termen convex between apex and $\mathrm{R}^{1}$, then considerably less so, not bent at $\mathrm{R}^{3}$, tornus pronounced ; cell $\frac{2}{5}$ or rather less ; $\mathrm{SC}^{2}$ separate, $\mathrm{M}^{1}$ separate. 
Type of the genus: Ignobilia urnaria (Guen.) = Ephyra urnaria Guen. (1858).

Differs from Somatina in the longer palpus, from nearly all its species likewise in the ontenna ; from Nobilia in $\mathrm{R}^{2}$ of forewing and separation of $\mathrm{SC}^{2}$ of hindwing ; from both, as well as from Orthoserica, in shape ; from Lissoblemma in the position of the dividing wall of the areole.

\section{Antitrygodes acinosa sp. n.}

Structure about as in dentilinea Warr. (1897). Forewing with termen slightly more sinuous, hindwing with the tooth at $\mathrm{R}^{1}$ rather more acute. Deeper purplish, the green blotches larger, including some partially rounded ones in the distal area.

São Thomé (T. A. Barns), recorded in Trans. Ent. Soc. Lond. 1927, p. 189, as dentilinea; type in coll. Joicey.

\section{Scopula ectopostigma sp. n.}

Face black. Antennal joints slightly projecting, ciliation scarcely over 1 . Collar buff. Hindtibia fringed with coarse scaling above and tufted at extremity, tarsus almost 1.

Forewing with cell noticeably over $\frac{1}{2}$; whitish, the irroration not strong, the lines light brown, rather weak ; cell-dot small but conspicuous.-Hindwing with termen very weakly toothed at $\mathrm{R}^{3}$; cell fully $\frac{1}{2}$; cell-dot and a line beyond ; terminal dot between $\mathrm{SC}^{2}$ and $\mathrm{R}^{1}$ strengthened.

Underside with cell-dot and traces of the lines beyond, forewing with smoky suffusion in cell.

Fernando Po, 3,000-4,000 feet, June 1926 (T. A. Barns), 1 ô, somewhat wasted but easily recognizable ; type in coll. Joicey.

\section{Scopula longitarsata sp. n.}

ơㅇ, 19-22 mm. Antennal joints projecting, the fascicles of cilia somewhat over 1. Hindtibia slender, of about the same length as femur, tarsus markedly longer.

Wings brownish white, with strong irroration, somewhat reminiscent of virgulata Schiff. (1775), but with sharper cell-dots, median and postmedian lines of forewing curved near costa, these lines on hindwing more proximally placed, terminal line more broken into dashes, hindwing beneath with postmedian line much more distal than above.

Kenya Colony : Kibwezi, April 1922 (W. Feather), 1 ô, 2 qq in Mus. Tring.

\section{Scopula nigrinotata (Warr.).}

Craspedia nigrinotata Warr., Nov. Zool. iv. 52 (1897) (Zomba).

This extremely variable species was founded on a white form with irregular blackish irroration. Two other colour-forms deserve names, as they probably indicate modifications due to the soil or rocks, as with many of the marginepunctata group.

Ab. uniformis ab. nov. is almost uniformly dusted with dark grey, closely like the Indian cleoraria (Walk., 1861), except in the less white subterminal spot. Type a f from Sabie, Transvaal (W. Grubb) in coll. L. B. Prout. 
Ab. argillacea ab. nov. Ground-colour more clayey, or inclining to cinnamon-buff. Rather prevalent about Cape Town and other parts of Cape Colony. Type a ô from Port Elizabeth (Fitz Simmons) in coll. L. B. Prout.

\section{Scopula cassioides sp. n.}

ơ우 23-25 mm. ô antennal ciliation shorter than in cassiaria (Swinh., 1904), hindtarsus about $\frac{2}{3}$ tibia.

Forewing rather more brownish than in cassiaria; median shade arising from a blacker costal spot, then weaker, much more angled outward at $\mathrm{R}^{1}$, postmedian also bent anteriorly._Hindwing concolorous.

Underside with the hindwing less strongly marked than in cassiaria.

Kenya Colony: Kibwezi (W. Feather), type ô and allotype + ; Mombasa (Doherty), 1 ô; all in Mus. Tring.

$S$. cassiaria, to which the new species is perhaps not really so closely related as it looks, has the of antennal ciliation about 2, the hindtarsus longer than the tibia, and is obviously very near accentuata (Guen., 1858).

\section{Scopula jejuna sp. n.}

Apparently a link between deserta (Warr., 1897) and dissonans (Warr., 1897 ) on the one hand, and bistrigata (Pagenst., 1907) on the other ; narrowerwinged than the two latter, hindwing somewhat more angled than in deserta. Cell-dots minute. Forewing marked almost as in weakly-marked deserta, the fringe pale; hindwing with postmedian line and subterminal shades bent or curved at $\mathrm{R}^{1}$. Face brown, not very dark.

S. Nigeria: Ogruga, type ㅇ. Cameroons: Joko, 1 ㅇ. Both in Mus. Tring.

\section{Scopula rhodocraspeda sp. n.}

Possibly a colour-form of bistrigata (Pagenst.) ; comparison difficult as the only of bistrigata yet known to me (Diego Suarez, 31 August) is very worn ; central shade obsolete above, as also the distal markings, which in bistrigata apparently connect the postmedian line with the apex. Mustard-yellow to apricot-yellow, the costal edge of the forewing rosy, also the fringes. Forewing beneath suffused with testaceous, only the hindmargin remaining pale.

Madagascar: Betsileo (Hildebrandt), 2 ôे $\hat{\sigma}$, type in Zool. Mus. Berlin,

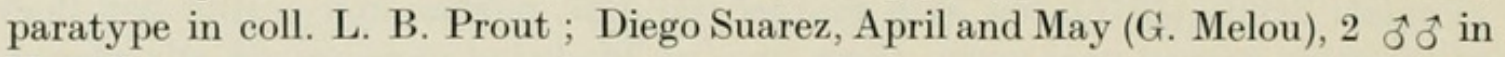
Mus. Tring.

\section{Scopula leucoloma sp. n.}

Closely related to rubrosignaria (Mab., 1900) = minuta (Warr., 1900, "S. America," ex err.), hindtarsus apparently a little shorter, wings slightly more rounded. Both, excepting the distal margins and parts of the other margins, strongly suffused with somewhat pinkish cinnamon; forewing with antemedian line more angled than in rubrosignaria, both wings with a strongly developed subterminal. Face burnt sienna, heavily dark-mixed above.

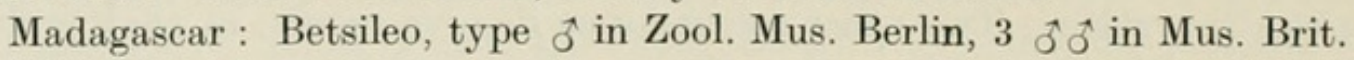

40. Scopula sanguinisecta subcatenata subsp. n.

More flesh-coloured than S. s. sanguinisecta (Warr., 1897), median line strongly incurved at fold, subterminal spots more numerous, though commonly weaker or anteriorly smaller, in the $q$ generally forming a complete chain. 


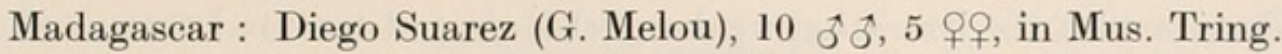

Of the above series, $1 \delta$ and $1+q$ have the ground-colour whitishab. albida ab. nov.

\section{Scopula batesi sp. n.}

ô, $30 \mathrm{~mm}$. Closely like a large, pale, weak-marked sanguinisecta (Warr.), the postmedian of the forewing slightly more sinuous, the hindtarsus only about $\frac{2}{3}$ (in sanguinisecta about 1).

Cameroons: Gendern, 4,600 feet, August 1921 (G. L. Bates), 1 ơ in coll. L. B. Prout.

\section{Scopula quintaria principis subsp. $n$.}

Differs from q. quintaria (Prout, 1916) in having the upperside almost pure white, the forewing beneath smoky proximally and with a postmedian line more or less developed (in q. quintaria almost as unmarked as in tricommata Warr., 1899). Joicey.

Principe, 1,500-2,000 feet, April-May 1926 (T. A. Barns), 6 우 in coll.

\section{Scopula aphercta sp. n.}

§ิำ, 22-25 mm. Size of nemorivagata (Wllgrn., 1863) = bonaventura (Warr., 1897), easily distinguished therefrom by the absence of the characteristic markings of the distal area, from fimbrilineata (Warr., 1902) by the smaller size and smoother wing-margins, from both by the merely curved, not angled, median shade of the forewing and the large cell-dot of the hindwing.

S. Nigeria and Belgian Congo, the type ô from Ogruga, Niger, in coll. Tring Mus. A very worn pair from Farniso, near Kano (N. Nigeria), December 1919 (A. Buchanan), also almost certainly belong here.

\section{Scopula suda sp. n.}

ô, $26 \mathrm{~mm}$. Antenna with fascicles of eilia rather long (about 2). Hindtibia with hair-pencils, tarsus little over $\frac{1}{2}$.

Forewing shining white ; costal edge buff ; lines not very sharply defined obsolescent anteriorly, the postmedian obscurely lunulate-dentate; no median shade; terminal line wanting.-Hindwing subquadrate, termen slightly sinuous ; as forewing.

Underside with costal edge of forewing black in proximal part, the entire cell smoky ; otherwise almost unmarked.

Lake Kivu: Rugege Forest, Ruanda district, 7,000 feet, December 1921 (T. A. Barns), 1 ơ in coll. Joicey.

\section{Scopula coniargyris sp. n.}

ㅇ, $24 \mathrm{~mm}$. Face black.

Forewing white, copiously and almost regularly sprinkled with black; celldot minute; lines pale buff, somewhat obscured by the black irroration, finer than the olive-buff lines of quadrifasciata (Bastelb., 1909) = glaucocyma (Hmpsn., 1910), much more sinuous, more as those of superior (Butl., 1878), etc. ; median line well beyond cell-dot, outer subterminal ill-defined, macular; terminal dots minute.-Hindwing shaped much as in superior, or with the bend at $\mathrm{R}^{3}$ slighter still ; lst line wanting, median proximal to cell-dot, the rest as on forewing. 
Underside with the irroration weaker, cell-dots and terminal dots as above, lines on forewing fainter and greyer, on hindwing obsolescent.

N.E. of Mweru: Lufonso River, E. Luvua Valley, 5,700 feet, February 1922 (T. A. Barns), 1 ㅇ in coll. Joicey.

\section{Scopula isomala sp. $\mathrm{n}$.}

Antennal ciliation of $\hat{o}$ longer than diameter of shaft, hindtibia strongly thickened, tarsus quite short.

Wings rather broad, both with the termen faintly sinuous; strangely similar to aequidistans (Warr., 1896) from Timor, of which only the type $q$ is known ; irroration darker, antemedian line of forewing right-angled in the cell, median less sinuous and more oblique than in that species.

Nairobi, 7 May 1911 (T. J. Anderson), type in Mus. Brit., where there is also a browner + , in poor condition but probably conspecific, from Mlanje, 2,300 feet, 29 August 1913 (S. A. Neave).

\section{Scopula stephanitis sp. n.}

o, 21-22 mm. Antennal ciliation nearly even, about 1. Hindtibial pencil strong, tarsus less than $\frac{1}{2}$. Recognizable by the faintly sinuous distal margins, the creamy white ground-colour and dark olive-buff costal edge and markings. Underside with sharp cell-dots, the other markings quite shadowy.

Virunga Mountains (Kivu), 9,000 feet, October 1921 (type) ; Kabira Forest (Ruanda), 7,000 feet. January 1924 (1 ô), both in coll. Joicey, collected by T. A. Barns.

Perhaps near caducaria (Swinh., 1904), but more recalls the South American abornata (Guen.).

\section{Scopula mollicula sp. $n$.}

Size, shape and coloration much as in caducaria (Swinh., 1904), but less glossy, perhaps better associated with the spoliata-lubricata group. Face whitish, only a little dark-mixed in upper part. Antenna of ô with fairly long ciliation, hindtibia strongly pencilled, tarsus short (about $\frac{1}{2}$ ).

Both wings with cell-dot strong; median and postmedian lines of forewing more distally placed than in caducaria, the latter marked with dark vein-dots; subterminal less strongly sinuous, its accompanying shades sometimes weak.

Underside paler, especially the hindwing, which has the lines obsolete.

Madagasear : Diego Suarez, a good series in coll. Tring Mus.

\section{Scopula crawshayi sp. n.}

o, $29 \mathrm{~mm}$. Larger than even the largest praeruptorum Prout (1920), considerably paler. Antenna subserrate, with longer ciliation. Hindtibia long, tarsus $\frac{2}{5}$ or slightly less. Both wings with postmedian line strongly inbent between the radials, but the forewing without the acute tooth on $\mathrm{R}^{1}$, on the other hand with a thickening in the sinus, as in caducaria (Swinh.) ; fringe slightly irrorated, but without definite black dots. Underside with forewing suffused to just beyond the postmedian, then whitish, the hindwing whitish, almost without markings except the cell-dot and terminal dots.

Kikuyu : Roromo, 17 February 1900 (R. Crawshay), 1 ơ in coll. Brit. Mus. 


\section{Scopula luxipuncta sp. n.}

o, $26 \mathrm{~mm}$. Antenna subdentate-fasciculate, the ciliation rather long. Hindtibia little dilated, but with a long pale hair-pencil; tarsus somewhat over $\frac{1}{2}$.

Forewing whitish buff, with more fleshy suffusion in distal area ; shadowy lines of the latter colour, the median excurved considerably beyond the strong black cell-dot, the postmedian black vein-dots exceptionally angled outward at $\mathrm{R}^{1}$ (where, moreover, the dot is elongate). Hindwing with termen waved, very slightly prominent at $\mathrm{R}^{3}$; marked nearly as forewing, median line proximal to cell-dot.

Forewing beneath irregularly suffused with grey proximally, cell-dot black, markings outside it greyer; hindwing almost unmarked, except cell-dot and terminal dots.

W. Kivu : Lowowo Valley, S. Lowa district, 4,000 feet, mountain forest, March 1924 (T. A. Barns), type ô and an ab. (?) rather duller and more weakly marked, but with stronger median shade of forewing; both in coll. Joicey. Kampala, Uganda, a ơ in Mus. Tring.

\section{Scopula cornishi sp. n.}

ơㅇ, 23-28 mm. In shape near luxipuncta, i.e. the forewing scarcely so broad and convex-margined as in praeruptorum Prout and improba (Warr., 1899). The whitish ground-colour shows, in fresh specimens, a strong fleshy suffusion; markings intermediate between those of luxipuncta and the improba group, the postmedian recalling the latter, the very distally placed median of forewing as in the former, but distinct from those of both in its less grey, more fawn colouring. Antenna of $\hat{o}$ nearly as in luxipuncta, hindtibia with normal hair-pencils, tarsus well over $\frac{1}{2}$.

Madagascar: Ambinanindrano, $50 \mathrm{~km}$. W. of Mohanoro (G. K. KestellCornish), type $\delta \hat{~(u n f o r t u n a t e l y ~ r a t h e r ~ w o r n) ~ a n d ~} 14$ 우 in Mus. Tring.

\section{Scopula astrabes sp. n.}

$\hat{o}, 16 \mathrm{~mm}$. Structure as in serena Prout (1920). Both wings appear slightly narrower still, the margins being less curved, the apex of the forewing rather sharp. Ground-colour much more fleshy and with stronger dark irrorations; lines greyer, much stronger, the median of the forewing crossing the cell-dot, the median and postmedian of the hindwing very straight, especially the latter, which approaches the cell-dot ; marginal shade stronger, the rather large terminal dots slightly connected by a grey line. Underside with similar distinctions.

Natal : Estcourt (J. M. Hutchinson), 1 ô in coll. Janse.

\section{Scopula oenoloma sp. n.}

ô, 25-27 mm. Face black. Vertex whitish. Antennal ciliation somewhat longer than diameter of shaft. Hindtibia of $\delta$ with hair-pencil, tarsus about as long as tibia.

Upperside variable in colouring, some specimens much paler than the ochreous type-form ; median shade more or less mixed with grey, postmedian line varying in thickness, sometimes marked with blackish dots on the veins; the 
vinaceous fringe (only proximally somewhat suffused with the ground-colour) is characteristic.

Underside always with the usual pale ground-colour of Scopula, only becoming more ochre at costal edge ; forewing proximally irrorated with black ; markings slight, especially on forewing; fringe vinaceous, with pale base.

Nyasaland: Mlanje Plateau, 6,500 feet, December and March 1913 (S. A. Neave), 4 oิ ô; Mt. Mlanje, 5,000-7,000 feet, 1 May 1910, 1 ô; all in coll. Brit. Mus.

\section{Scopula benenotata sp. n.}

Craspedia benenotata Warr. M.S.

o, $26 \mathrm{~mm}$. Similar in structure to latitans Prout (1920). Forewing a little narrower, with termen somewhat more oblique ; colouring warmer, pinkish buff or light pinkish cinnamon, cell-dots larger, postmedian line marked with angular black dots or short teeth outward on the veins and on the hindwing with a large black dot at abdominal margin ; fringe with small dots at base opposite the veins.

Madagascar: Ivohimanitra Forest, Tanola, 21 October 1894 (F. Major), 1 ô in Mus. Tring.

\section{Zygophyxia palpata sp. n.}

ㅇ, $18 \mathrm{~mm}$. Face and palpus brown, the latter much more heavily scaled than in typical Zygophyxia. Wings less extremely narrow than in relictata (Walk., 1866), white with moderately dense but unevenly distributed brown-grey irroration, the median shade proximal to the cell-dot on both wings, the subterminal strong, band-like, parallel with termen. Hindwing with a terminal excision between $\mathrm{M}^{2}$ and tornus, as in tornisecta Prout (1916).

Kenya Colony : Kibwezi, April 1922 (W. Feather), type in coll. Tring Mus.

Palpus rather more robust than in tornisecta, wings slightly narrower, whiter, the lines less brownish, etc.

\section{Zygophyxia erlangeri sp. n.}

In structure and coloration close to relictata (Walk.), in markings nearer to tornisecta Prout. Only the cell-dots and the band-like outer line distinct, both above and beneath; hindwing not noticeably paler than forewing; terminal marks punctiform (in relictata linear); underside of palpus and of wings paler than in relictata.

Merehan: Djeroko (type) and Wante; Garre; Gardoba-Djira ; KaroLola, S. of Dana River; Gorgoru, Ganale River ; a series of 10 우 collected in April-May 1901 (Baron C. von Erlanger), all in Mus. Tring.

\section{Ptychamalia gen. n.}

Head, antenna, thorax and leg-structure as in Scopula, the o hindleg occasionally (exempta, costifera, ptychopoda, etc.) with a tendency to lose the outer proximal spur._-Forewing with termen smooth, at most very faintly sinuous ; cell less than $\frac{1}{2}$; areole double, $\mathrm{SC}^{2}$ arising from cell, occasionally connate, extremely rarely stalked or with its base lost (leaving the areole undivided), $\mathrm{R}^{2}$ central or a little before middle._Hindwing with termen rounded, or very feebly bent in middle ; C normal, $\mathrm{SC}^{2}$ stalked, $\mathrm{M}^{1}$ separate, often rather widely so. 
Type of the genus : Ptychamalia perlata (Warr.) = Haemalea perlata Warr. (1900).

An extensive genus, of very uniform facies, which has been confused with Hamalia $\mathrm{Hb}$. but differs essentially in the ô genitalia, which are more Sterrha-like in structure - gnathos present, valves not fused, no cerata - while Hamalia more favours Scopula. Of the superficial characters which are generally used in Sterrhine taxonomy, no single one seems absolutely valid in all cases, though the hindwing venation ( $\mathrm{SC}^{2}$ in Hamalia connate or just separate, only exceptionally short-stalked ; $\mathbf{M}^{1}$ closely approximated or almost connate) will generally suffice, while the rather more robust build of Hamalia, its more aborted os hindleg and sometimes hindwing specialization are also of differential value. From Scopula, Ptychamalia differs regularly in the stalking of $\mathrm{SC}^{2}$ of the hindwing and almost invariably in the double areole of the forewing.

\section{Ptychamalia sara sp. n.}

ô, 20-21 mm. Smaller than nigromarginata (Dogn., 1890). Forewing with antemedian line generally complete, sinuate inward between $\mathrm{M}$ and $\mathrm{SM}^{2}$, the diffuse median shade replaced by a concise line (rarely thick) just beyond the cell-dot, minutely dentate outward on the veins, gently incurved between $\mathbf{M}^{1}$ and $\mathrm{SM}^{2}$; postmedian with its oblique anterior part prolonged so as to touch (or almost touch) the terminal bloteh just behind $\mathrm{R}^{1}$.

Bolivia: Prov. del Sara, Dep. Sta. Cruz, January (a series), May (1 ô), type in coll. Joicey.

\section{Ptychamalia melanoma sp. n.}

ô, $19 \mathrm{~mm}$. Face blackish brown, narrowly white below. Palpus white at base and beneath, partly brown on outerside. Antennal fascicles 1 or slightly over. Hindtibia rather long, strongly dilated, with white pencils, tarsus very short.

Forewing rather narrow; both areoles rather long, $\mathrm{SC}^{2}$ from cell ; white, with minute and sparse dark irroration; costal edge black to about middle; cell-dot moderate; antemedian and median lines sinuous, weak, the former crossing base of $\mathrm{M}^{2}$, the latter just outside cell-dot ; postmedian marked chiefly by dark vein-dots and blacker dots at both margins, running from costa $2.5 \mathrm{~mm}$. before apex, slightly oblique outward to $\mathrm{R}^{1}$, then slightly less oblique than termen to $\mathbf{M}^{1}$, finally almost parallel with termen and with fine interneural lunules ; vague dark subterminal shading, stronger as an elongate mark between $\mathrm{SM}^{2}$ and tornus ; terminal line black, slightly interrupted._Hindwing rather elongate costally, termen anteriorly rounded, near tornus straighter to faintly subconcave ; median line continuing antemedian of forewing, postmedian continuing median; subterminal shades a little strengthened.

Underside more weakly marked, the cell-dots and postmedian well noticeable, especially on forewing; forewing slightly suffused at base, brown-tinged along costal margin, the black proximal edging less long than above.

Matto Grosso: Urucum, near Corumba, January-February 1928 (Cesar Cascano), 1 ô in coll. Joicey.

Near ptychopoda (Prout, 1910) in size, shape and ground-colour, but with the darkened costa of perlata (Warr.), costifera (Dyar, 1914), etc. 


\section{Tricentrogyna gen. $\mathrm{n}$.}

General characters of Sterrha Hb. (=Ptychopoda $\mathrm{Hb}$.), but with 3 spurs ( 1 proximal, 2 terminal) on the $q$ hindtibia. Generally further differentiable by the double areole of the forewing, but I include here, at least provisionally, a few aberrant forms in which the areole is simple or even obsolete. Hindleg of $\hat{o}$ spurless, generally slender. Distinguishable from the 3-spurred Eumacrodes by the less elongate abdomen and wings and shorter cells, generally also (though I include here lignicolor Warr., 1904, and informipennis Warr., 1905) by the more regular shape of the hindwing; from the occasional 3-spurred Ptychamalia, apart from the pattern, by the stalking of $\mathrm{R}^{3}$ and $\mathrm{M}^{1}$ of the hindwing.

Type of the genus: Tricentrogyna vinacea (Butl.) =Hyria vinacea Butl. $(1878)=$ Acidalia flavomarginata Möschl. $(1890)=$ Acidalia opulentaria Möschl. (1890).

\section{Lobocleta isocyma sp. n.}

ㅇ, $20 \mathrm{~mm}$. Face blackish. Palpus short and slender, blackish-mixed on outerside. Vortex pure white; occiput and collar more buff. Thorax and abdomen white, irrorated with buff.

Forewing white, with some very fine buff irroration ; markings buff (inclining to pinkish buff), band-like; basal and subbasal ill-defined, partly interrupted, partly confluent; antemedian more definite, as oblique as termen ; median, postmedian and subterminals parallel, sinuous (inward at both folds, outward before, between and behind), separated by bands of the ground-colour scarcely as broad as themselves, the distal subterminal smooth-edged distally, separated from termen only by a white thread; terminal line very fine, but marked with dark dots at the veins ; three darker dots at apex and on distal part of costa ; fringe white, very weakly clouded with buff._Hindwing similar ; termen very faintly sinuate between the radials and behind $\mathrm{M}^{2}$.

Forewing beneath more suffused; hindwing white, feebly marked.

Matto Grosso : Melguira, 10 miles S. of Diamantino, 2,000 feet, 23 May3 June 1927 (C. L. Collenette), 1 \& in coll. Joicey.

A quite distinct species, somewhat recalling the African Scopula quadrifasciata (Bastelb., 1909), but without the minute black cell-dots.

\section{Sterrha inquisita sp. $\mathrm{n}$.}

+, $16 \mathrm{~mm}$. Face and palpus purple. Vertex buff-yellow. Body buffyellow, the abdomen above much clouded with dull purple. Legs predominantly yellow, anterior coxa and femur marked with purple.

Forewing scarcely so extremely narrow as in exquisita (Warr., 1897) and angusta (Butl., 1896); glossy eream-buff, clouded with buff-yellow ; markings livid purple or slightly redder ; basal patch $3 \mathrm{~mm}$. long in cell, narrowing behind ; subterminal band 1-1.5 mm. wide, sinuous-edged, at hindmargin reaching tornus. Hindwing gently sinuate between the radials, straightish between $\mathrm{M}^{1}$ and tornus; a subterminal band nearly as on forewing.

Underside similar, the proximal patch rather weaker.

French Guinea, Beyla, 1,900 feet, 15-17 July 1926, at light (C. L. Collenette), type in coll. Joicey. An identical but damaged o from Fort Grampel, French Congo, in coll. L. B. Prout. 
Possibly a race of exquisita (Warr.), the basal patch shorter anteriorly, the band more proximal.

\section{Sterrha prionodonta sp. n.}

ㅇ, 17-21 mm. Larger and relatively longer-winged than fumilinea (Warr., 1903), paler and with scarcely any black irroration. The principal lines more acutely angulated, the median more distally placed, faint, brownish, on the forewing arising from a black costal spot, very acutely angled outward at $\mathrm{R}^{1}$, then curving inward to the base of the medians ; black dots on fringe intense. Underside very faintly marked, excepting a postmedian costal dot and the fringe-dots.

Senegambia : Thies, 3 February 1907 (Riggenbach), type in coll. Tring Mus. W. Togoland, a + in Zool. Mus. Berlin.

\section{Sterrha tristega sp. n.}

of 14-22, mm. Face black. Antenna of of with the joints projecting, bearing rather long fascicles of cilia. Hindleg of os less short than in fumilinea Warr., the tibia heavily scaled above and with a hair-pencil from the femorotibial joint, the tarsus quite short (about $\frac{1}{3}$ ).

Variable not only in size but also in the warmth of the ground-colour, which, however, always shows a decided tinge of reddish or cinnamon-brown; the dark shading between the postmedian and subterminal lines recalls that of the Palaearetic trigeminata (Haw.) though each pair of "twin" spots is generally more confluent; the nearest affinities, however, seem to be evidently with fumilinea, from which it differs in having the markings less coarse (on the hindwing generally weaker), the median shade generally weak, the ante- and postmedian lines less irregular.

Madagascar : Diego Suarez (G. Melou), a long series in Mus. Tring.

\section{Sterrha leucorrheuma sp. n.}

ô, $14 \mathrm{~mm}$. Palpus minute, grey. Tongue wanting (?). Antenna rather slender, joints scarcely projecting, ciliation about 2. Hindleg short, the tibia and tarsus together very little longer than the femur.

Forewing with tornus slightly more pronounced than in the fumilinea group ; cell just over $\frac{1}{2}$; whitish, slightly glossy, mostly suffused with mousegrey, in places with some coarse darker irroration; a narrow band (shaped almost as in nexata $\mathrm{Hb}$.) remaining white between the median and postmedian lines, the rest of the median area intermediate in whiteness ; median line thick ; the white subterminal almost as sinuous as in fumilinea (Warr.) but less thickened; fringe dark-mottled, with blackish dots._Hindwing with termen strongly convex, more sinuous than that of forewing; $\mathrm{SC}^{2}$ short-stalked ; marked nearly as forewing.

Underside similarly but still more sharply marked.

Cape Colony: Oudebosch, December 1920 (Museum Expedition), 1 ô in coll. South African Museum.

\section{Sterrha staudingeri nom. n.}

Acidalia uniformis Stgr., Iris, x. 308, t. iv. f. 33 (1897) (nom. praeocc.) (Palestine).

"Leptomeris (?)" uniformis Warr., Nov. ZooL. iii. 373 (1896) is a Sterrha (vide Ins. Samoa, iii. (3) 131) and involves renaming Staudinger's species. 


\section{Sterrha swinhoei nom. n.}

Sterrha rufula Swinh., Ann. Mag. Nat. Hist. (7) xii. 199 (1903) (nom. praeoce.) (Borneo).

"Eois (?)" rufula Warr., Nov. Zool. vi. 334 (1899) is also a Sterrha, perhaps a form of $S$. uniformis (Warr.), but in any case invalidating S. rufula Swinh. (see on Anisodes connexa, no. 15 supra).

\section{Sterrha heres sp. n.}

Near associata Warr. (1897), but with the of antennal joints projecting almost as in echo (Prout, 1916); ciliation even, about 1. Cell-dots wanting or very faint, the shade just outside the postmedian also obsolescent or very narrow, even the characteristic darkening at the abdominal margin of the hindwing generally scarcely noticeable ; a fine, almost straight median line, on the contrary, generally well developed on the forewing. Underside similar to upper, the celldots sometimes better expressed. \& rather larger than $\hat{\sigma}$.

S. Rhodesia : Wankie (C. W. Tyler), a short series, type in Transvaal Mus. E. Africa: Kilwa, 1 ㅇ in Zool. Mus. Berlin.

\section{Sterrha poecilocrossa sp. n.}

o우, 9-13 mm. Hindtibia of $\hat{\mathrm{o}}$ with long, slender pencil, tarsus very short.

Forewing narrow, with cell very long; whitish ; easily known by its thick, sinuous postmedian line (placed unusually close to termen), its delicate violet-grey subterminal shading, warm brown costal edge and fringe, etc. ; cell-dot black, median line nearly straight, proximal to it._Hindwing with termen rounded anteriorly and only very faintly sinuate posteriorly ; distally similar to forewing, proximally a trifle more weakly marked.

Madagascar : Diego Suarez (G. Melou), a long series ; type in Mus. Tring.

\section{Sterrha simonsi nom. n.}

Odontoptila marginata Warr., Nov. Zool. xi. 38 (1904) (nom. praeocc.) (Bolivia).

"Hyria" marginata Swinh. (1894), which is likewise a Sterrha, invalidates Warren's name.

\section{Sterrha prucholoma sp. n.}

o우 $16-17 \mathrm{~mm}$. Face and upperside of palpus blackish. Tongue well developed. Antennal ciliation of $\hat{\sigma}$ rather short. Vertex whitish. Collar and front of thorax above brown. Body otherwise concolorous with wings. Hindleg of $\hat{o}$ formed much as in inversata Guen. (= costaria Turn., Proc. Linn. Soc. N. Sth. Wales, xxxi, p. 645 , nec Walk.), the tibia rather short and broad, heavily fringed, the tarsus long, broad and flattened (? "paddle-shaped" of Turner, ibid., p. 647).

Forewing shaped about as in marginata Swinh. (1894); areole rather small, $\mathrm{SC}^{1}$ generally separating beyond its apex ; in colour and markings extremely like a rather pale marginata; the purple-brown border with the proximal projections rather strong between the radials and in the submedian area.Hindwing with the termen not-as in marginata - appreciably bent at $\mathrm{R}^{3}$; concolorous with forewing ; the irregular border broadest apically or subapically.

Underside similar, with the markings slightly broadened and strengthened, forewing proximally somewhat suffused, posteriorly and distally (with hindwing) a trifle paler than upperside. 
Uganda (G. H. E. Hopkins), the type $q$ in good condition from M. 11, Jinja, 12 April 1931, a worn ô allotype (recognizable, useful for the structural characters), 25 May 1931, both in Mus. Brit. The Tring Museum has a smaller $\hat{o}$, also in poor condition, from Kumasi, Gold Coast, and another from Kassai district, Congo Belge (Taymans).

\section{Sterrha tornivestis $\mathrm{sp} . \mathrm{n}$.}

$\hat{o}+19 \mathrm{~mm}$. At least as long-winged as flamingo (Warr., 1901), but with the distal margins not sinuous. Pale, not reddish, the postmedian line pretty direct but slight, subterminal shades strong, in the $f$ more or less suffusing with the postmedian to form a broad dark border. ot hindwing at tornus and distal part of abdominal margin clothed with long coarse specialized scaling which projects somewhat beneath.

Nairobi, a few of each sex in different collections, the type of, 28 April 1928 (G. H. E. Hopkins), in coll. Joicey. Also 1 from Mt. Mlanje, 2,300 feet (S. A. Neave), in coll. Brit. Mus.

\section{Sterrha falcifera nom. n.}

Deinopygia falcipennis Warr., Proc. U.S. Nat. Mus. xxx. 438 (1906) (nom. praeocc.) (Mexico).

So long as Deinopygia is regarded as a section of Sterrha, Warren's name for this species is preoccupied by ["Idoea "] Sterrha falcipennis Warr. (1893) from Sikkim.

\section{Sterrha zonata nom. n.}

Xenocentris fasciata Warr., Nov. Zool. v. 245 (1898) (nom. praeocc.) (Queensland).

There exists a prior fasciata in the genus Sterrha (sect. typ.), namely $S$. fasciata (Stgr., 1892, Taurus), which, although almost certainly a race of determinata (Stgr., 1876), preoccupies the binomial.

\section{Sterrha villitibia sp. $\mathrm{n}$.}

o, $22 \mathrm{~mm}$. Antennal ciliation very short. Midleg rather long and strong, tibia clothed with very long shaggy hair, tarsus shorter than tibia; hindleg short, weak, hairy, the tarsus aborted. Head and body concolorous with wings, vertex of head more smoky, face blackish.

Forewing with termen slightly more oblique than in proximaria (Leech, 1897 ) ; areole moderate, $\mathrm{SC}^{1.5 .2 .3 .4}$ stalked well beyond it ; light vinaceous-buff, a little warmer and more uniform than in proximaria, but closely similar ; markings as in that species, rather weak, darkening of costal edge slighter and narrower. Hindwing with apex well expressed, termen long, from apex to $\mathrm{R}^{2}$ straight, then gradually curving, more sharply bent about the medians, submedian area relatively reduced, abdominal margin long ; underside clothed with moderately appressed hair ; $\mathrm{SC}^{2}-\mathrm{R}^{1}$ stalked to about $\frac{1}{3}$ their length ; as forewing.

Underside more weakly marked, the dark terminal shade undeveloped.

W. China: Kwanhsien, Szechuan, 16 August 1930 (G. M. Franck), 1 o in coll. L. B. Prout.

Apparently a highly specialized development of proximaria (Leech), the hindwing shape recalling that of informis (Warr., 1897, as Strophoptila) or some specialized South American Sterrha. 


\section{Sterrha rufulata versicolor subsp. n.}

Rather larger than typical rufulata (Warr., 1900, as Pogonogya, Venezuela), hindwing above more strongly irrorated with red, beneath with a broad red band distally, occupying more than half of the wing, only shading off to the ground-colour towards tornus.

Matto Grosso : Melguira, 10 miles S. of Diamantino, 2,000 feet, 23 May3 June 1927 (C. L. Collenette), type ô in coll. Joicey. E. Bolivia : Buenavista (J. Steinbach), in coll. Tring. Mus.

\section{Sterrha caustoloma sp. n.}

+, $16 \mathrm{~mm}$. Evidently near ustimargo (Warr., Proc. U.S. Nat. Mus. xxx. 459, as Ptychopoda, Dutch Guiana), which is only known to me from the description. Structure the same, also the purple (overlaid with glossy blue-black) head, dorsum of abdomen and costal margin of forewing.-Wings pinkish buff, in some lights with violet or bluish-silvery reflections ; cell-dots present; all three lines marked by dark vein-dots, the postmedian of the forewing the blackest and most distinct, connected by traces of a very fine dark thread; different from that of ustinargo in that it curves after reaching $\mathrm{R}^{3}$, thence running parallel with termen at a distance of about $1 \mathrm{~mm}$., bending out towards tornus behind $\mathrm{SM}^{2}$; distal area not filled in with purplish grey, merely with faint shadowing proximally to the thick blackish-purple terminal line, which is almost interrupted about $\mathbf{M}^{1}$.

Matto Grosso: with the preceding species, 3 우요

\section{Sterrha buchanani sp. n.}

"Sterrha fylloidaria Swinh." Rothsch. Nov. Zool. xxviii. 216 (1921) (err. det.).

ㅇ, $14 \mathrm{~mm}$. Smaller than fylloidaria (Swinh., 1904), apex of forewing and termen of both wings somewhat more rounded. Paler grey-brown, not reddish ; postmedian line much weaker, about parallel with termen, thus more proximally placed at the angle on $\mathrm{R}^{1}$, which angle is less extremely acute ; subterminal band stronger, approximately parallel with termen; hindwing less contrasted in colour within and beyond the postmedian line.

Makochia, Damagarim, 15 September 1920 (A. Buchanan), 1 o in Mus. Tring.

\section{Sterrha lycaugidia sp. n.}

ôㅇ, 14-18 mm. In shape and general aspect, as well as in having $\mathrm{C}$ of the hindwing anastomozing with the proximal half (or more) of the cell, evidently related to lilliputaria (Warr., 1902). of antennal joints projecting, with paired fascicles of cilia. ô hindtarsus long (in lilliputaria very short). More Zygophyxialike than the following species and lilliputaria, the postmedian line of the forewing very oblique, the hindwing only with cell-dot and a weak line beyond.

Madagasear : Diego Suarez (G. Melou), a long series in coll. Tring Mus.

\section{Sterrha sympractor sp. n.}

ofo, 13-15 mm. On an average smaller than the preceding, still nearer to lilliputaria (Warr.) in shape and markings, but somewhat browner, with stronger grey irroration or suffusions, the lines commencing from black costal spots. 
$\hat{\sigma}$ antennal ciliation rather short. $\hat{o}$ hindtarsus about $\frac{1}{2}$. Venation as in lilliputaria.

Madagascar : Diego Suarez (G. Melou), a long series in coll. Tring Mus.

Notiosterrha gen. $\mathrm{n}$.

Face rounded, protuberant, smooth-scaled. Palpus shortish, rather stout, terminal joint small. Tongue developed. Antenna in $\hat{\sigma}$ with shaft almost simple, bearing fascicles of long cilia. Pectus somewhat hairy. Femora glabrous. Hindleg of $\delta$ rather long, tibia not dilated, bearing a pair of well-developed terminal spurs, tarsus long; + probably with terminal spurs only.-Forewing with costa rather strongly shouldered at base, then very straight to near apex, termen rather short, nearly straight, not very strongly oblique; cell almost $\frac{3}{5}$, $\mathrm{DC}^{1}$ well developed, areole single, ample, $\mathrm{R}^{2}$ slightly before middle, $\mathrm{M}^{1}$ rather widely separate._Hindwing with costal margin relatively long, apex rounded, termen smooth, straightish between $\mathrm{R}^{1}$ and $\mathrm{M}^{2}$, straight or almost incurved between $\mathrm{M}^{2}$ and tornus ; cell at least $\frac{1}{2}$; $\mathrm{C}$ normal, $\mathrm{SC}^{2}$ very shortly stalked, $\mathrm{R}^{2}$ slightly before middle, $\mathrm{M}^{1}$ well separate.

Type of the genus: Notiosterrha rhodocosma (Lower) = Sterrha rhodocosma Lower (1897).

The shape and texture of the type more recall Omphax bacoti Prout (1912) than the ordinary Sterrhine forms, though the termen of the forewing is slightly shorter and less oblique still. Comparison is also possible with Rhodometra, which has - except for still longer cell of forewing and strong anastomosis of C of hindwing - similar venation, similar colouring, similar hindwing, protuberant (though less rounded) frons, but which is, I think, not quite so robust and has considerably longer and more oblique termen of forewing and strongly pectinate ô antenna. Distinct from Sterrha in the frons, long cells, wing-shape, very short stalking of $\mathrm{SC}^{2}$ of hindwing, etc.

Here will probably belong aglaodesma (Lower, 1893), interalbulata (Warr., 1904) and triglypta (Lower, 1908); the last-named, described as "Dichromodes ?", must, I think, be near interalbulata, though much larger-unless " $28 \mathrm{~mm}$." is a misprint. 


\section{$2 \mathrm{BHL}$ Biodiversity Heritage Library}

1932. "New genera and species of Sterrhinae (Fam. Geometridae)." Novitates zoologicae : a journal of zoology in connection with the Tring Museum 37, 229-251. https://doi.org/10.5962/bhl.part.13263.

View This Item Online: https://www.biodiversitylibrary.org/item/22933

DOI: https://doi.org/10.5962/bhl.part.13263

Permalink: https://www.biodiversitylibrary.org/partpdf/13263

\section{Holding Institution}

Natural History Museum Library, London

\section{Sponsored by}

Natural History Museum Library, London

\section{Copyright \& Reuse}

Copyright Status: In copyright. Digitized with the permission of the rights holder.

Rights Holder: The Trustees of the Natural History Museum, London

License: http://creativecommons.org/licenses/by-nc-sa/4.0/

Rights: http://biodiversitylibrary.org/permissions

This document was created from content at the Biodiversity Heritage Library, the world's largest open access digital library for biodiversity literature and archives. Visit BHL at https://www.biodiversitylibrary.org. 